\title{
FEATURES OF THE PROMOTION POLICY OF THE CONFECTIONERY INDUSTRY
}

\author{
Myroslava Mokliak, Ph.D., Associate Professor \\ Yaroslav Perederii \\ Poltava National Technical Yuri Kondratyuk University \\ Mykola Safonov, businessman of LTD "Diamond LTD"
}

\author{
(C) Mokliak, M., 2019 \\ (C) Perederii Y., 2019 \\ (C) Safonov M., 2019
}

Стаття отримана редакиією 16.02.2019p.

The article was received by editorial board on 16.02.2019

A fundamentally important role of marketing is already a long-known truth. In addition this statement is relevant to enterprises of any branch of the economy.

One of the most important components of marketing policy is the promoting policy of the company's good/services on the market.

A promotion is any form of communication that an enterprise or organization uses to inform, convince, remind of oneself, one's goods and/or services. Promotion in marketing is a complex as it combines a number of elements with their qualities: advertising, public relations, sales promotion, personal sales, etc. Accordingly, a range of promotion is a set of means of influence the target market segments or other target audiences in order to form a favorable attitude towards the enterprise, its goals and objectives, goods and / or services.

The topic of work is relevant as in most enterprises the problem of product promotion is critical. The problem is due to increased competition in goods markets, competition from foreign and the largest domestic producers, as well as from a number of small businesses. Nowadays most companies ignore the importance of marketing element such as product promotion on the market. Therefore, it is very relevant to consider this issue more detailed.

The theoretical basis and various aspects of the practical application of product promotion were studied by such domestic and foreign scientists: Yu. S. Apchel, I. E. Astakhova, S. V. Blyzniuk, S. I. Bai, L. V. Balabanova, V. M. Heiets,, N. S. Illiashenko, S. V. Kovalchuk, M. Ya. Matviiv, P. Sabluk, L. V. Novoshynska, N. I. Chukhrai, V. V. Bozhkova, A. E. Voronkova, E. N. Holubkova, M. H. Karhapolova, I. H. Klimova, I. V. Krasnokutska and others.

The research object of this work is the promotion policy of confectionery products of Private Joint Stock Company (PJSC) "Dominic".

The subject of the study is a set of theoretical, methodological and practical aspects of the implementing marketing tools for product promotion process.

Tasks set in this paper are:

- to define the gist of marketing promotion concept;

- to analyze the basic approaches to the marketing promotion classification;

- to consider the main ways of effective organization of development of product promotion means on the market;

- to give a description of the market and the competitive environment of PJSC "Dominic".

In order to ensure the effective enterprises functioning, it is necessary to implement the whole marketing complex. Effective management skills need to be applied to successfully implement elements of a marketing complex.

Ensuring and maintaining the competitiveness of enterprises in these conditions should depend primarily on the management quality of the marketing policies. 
The formation of the promotion complex determines the structure and tasks of the promotion marketing policy, creation of the system of general principles, criteria and guidelines in the field of relations between the enterprise or organization, on the one hand, and with consumers or other contact audiences, on the other hand, in order to achieve marketing goals, goals of the enterprise and creation of conditions for the implementation of its mission on the market.

Promotion policy is part of mass communication. During the current development state of communication processes, the increasing role of public opinion in Ukraine, each enterprise has the need for systematic informative and analytical, coordinating and influential-controlling actions aimed at establishing relations with the public and its individual groups. Particular attention should be paid to strengthening the enterprises' orientation actions to the demands of society, which involves improving the use of the promotion policy.

Analyzing various information sources one can see that the term "promotion policy", even within a single science, characterizes different processes. In our opinion, the most generalized and comprehensible is the interpretation of N. S. Palii [1, p. 98]: "The promotion policy is the process of sharing meaningful information and psychological energy between people through various means of communication, signs and symbols, with the aim of establishing bilateral psychological contact and creating conditions for the normal functioning of people, organizations and society as a whole". In the author's opinion, this definition made it possible to look at the communicative process in a new way and build its complex model, which differs from others while taking into account individual and mass communications; the presence of intelligent information and psychological energy flows coming from one to another in the information space. In this case, the types of communicative messages vary depending on their direction and form depending on the output and perception of these messages by the subjects on the way of information movement [2, c.145].

The concept of "promotion policy" by a large number of authors is identified with the marketing communications policy of the enterprise. This approach is used from a long time ago, but it is important to note that, in addition to the elements of the promotion complex, the communicative functions are endowed with the rest of the elements of the marketing complex. Marketing communication policy is a broader concept, due to the presence of multilateral communication links between market subjects not only when the goods arrive from the manufacturer to the consumer, but also during market research, due to the development of a new product, the adjustment of supplies and materials delivery, the performance of financiallycalculated operations, creation of a positive image of the enterprise, formation of relations with the public. Promotion of products in the market is carried out only at the stage of receipt of goods from manufacturer to consumer and along with communicative functions should include actions related to the establishment of the final price, the formation of an effective distribution system [1, p. 117].

Thus, the promotion policy is the information-psychological link between market subjects (consumers, suppliers, intermediaries, etc.) that are established to ensure their economic activity in order to maintain long-term mutually beneficial relations between them in the process of creating certain values. Marketing promotion policy is a promising course of action of the company, aimed at ensuring interaction with all subjects of the marketing system in order to meet the consumers' needs and get the profit.

Promotion policy is implemented through a suitable process of many elements:

- sender (source of information) - an enterprise that offers its goods and services and sends relevant information about them, addressing it to its target market;

- coding is a representation of the idea of a promotion policy, which transmits the information to the addressee in the form of texts, symbols and images; 
- addressing - this information is addressed to the target audience, presented in the form of a character set;

- channel of promotion policy - means of information distribution, its specific carriers;

- decoding is a decoding of the addressing when the characters which are received by the channels of promotion policy acquire specific values $\mathrm{n}$ the consumer's presentation in the consumer's imagination;

- the recipient is the consumer to whom the information about the goods or services of the enterprise is transmitted;

- reverse reaction - consumers' feedback, their actions in response to receiving and decoding addressing;

- feedback is part of the reverse reaction that becomes known to the sender;

- Obstacles - unplanned distortion of information as a result of interference in the promoting of environmental factors policy process [3, p. 225].

It is worth noting that the objectives of the promotion policy can be divided into two groups:

- promotion policy for the purpose of creating goods that will be in demand on the market;

- promotion policy for the purpose of promoting goods [2, c.120].

Communication tools used for this purpose are: advertising, sales promotion, personal sales, public relations, propaganda, direct marketing, etc. [4, p. 23]. Marketing promotion policy uses elements of the promotion complex as an arsenal of communication tools. Communication - in the broadest sense - is the process of information exchange.

The marketing promotion policy is often identified with the marketing communications of the enterprise. This approach has established traditions, but it is advisable to point out that, in addition to the promotion elements, communicative functions are allocated in the rest of the elements of the marketing complex. In particular, the product itself in real implementation may already have its own communication (for example, I see the bread - I feel hunger - I buy a purchase); this is the same for the price and place of sale (I see the goods in a convenient place for me - I need it - I can or can not buy it). However, the elements of the marketing promotion complex have the greatest impact on communication.

Therefore, we propose to consider the promotion policy as the system of means of influence on the market relations subjects, which is connected with the establishment of bilateral relations in order to obtain a communicative and economic effect. It is worth noting that each communicative solution, selected from the numerous existing means, methods, models, methods of promotion policy, directly affects the level of interest from consumers to the enterprise and its products. Further retention of this interest, even in mature, sustainable markets, essentially depends on the effective conduct of marketing communication policy [5, c. 55].

The variety and amount of means and methods of promotion policy is a very obvious fact. Indeed, for the establishment of the desired interconnections with specific destinations addressee, the sending company can use such a powerful means as advertising in its various manifestations. The communicator can also attract the attention of consumers or intermediaries with the help of public relations methods. They can be an editorial article in a newspaper or magazine about the use of new technologies by the company; an interview with the head or employee of the firm on television or radio; specific video, where along with the beauty of nature "accidentally" falls into the frame the company's products, etc.

The above mentioned main means of promotion policy (advertising, public relations, sales promotion and direct marketing) form a complex, sometimes referred to as a marketing mix $-\mathrm{a}$ "communication mix" or a "promotional mix" (promotion blend).

The promotion complex creates a communicative influence through the actions of its elements. Among the main elements are the following:

1. Advertising is any form of non-personal paid representation and promotion of products, services and ideas on behalf of and at the expense of their manufacturer or owner (intermediary, etc.). Main features of advertising are: 
- wide reach of the audience;

- cheap per one recipient;

- repeating a message repeatedly;

- enables the company to present the goods effectively and clearly;

- impersonal character;

- advertising is a monologue;

- very expensive (TV commercials) [5, c.102].

2. Stimulating the sale of goods - short-term measures to encourage participants of marketing communications to purchase, obtain additional information or to further resell these products. The main features of sales promotion are:

- informative;

- attractiveness;

- invitation to purchase;

- the short-term nature of the effect in the growth of sales [6, c. 65].

3. Public relations is a complex of actions of a non-profit nature aimed at the formation, maintenance or restoration of a positive image of the subject of politics, state or entrepreneurship (political personality, party, state institution, enterprise, separate product) because of the distribution of important information of propaganda or prestigious nature in the media or on the stage (arena, podium). The key features are:

- high degree of certainty;

- broad reach of the target audience;

- effective presentation of goods [6, c. 131].

4. Personal sale is an oral presentation of a product in the process of conversation with one or more buyers (actual or potential) for the purpose of concluding with agreement (contract) for the purchase of the goods. The key features of Personal Sales are:

- direct nature;

- promotes the establishment of long personal relationships;

- implies a certain reaction of the buyer;

- the most expensive type of communication (per one contact);

- difficulties in the case of changing the sales staff [7, c. 77].

5. Direct marketing is a kind of marketing that uses advertisements to directly address a potential consumer to gain feedback without interruptions of retail or personal sales. The types and characteristics of direct marketing are:

- non-massive: the message is addressed to a specific person;

- customer-oriented: the message can be changed during the addressing to a specific person;

- operational: the message to a particular person can be compiled very quickly;

- updated: message can be changed [8, c.78].

Today there is a further differentiation of marketing policy tools. Such tools as branding, sponsorship and prestigious advertising have been distinguished from public relations. They are perhaps the most important in modern marketing, especially branding (brand development) and prestigious advertising (promoting the activities of the enterprise as a whole or some kind of "prestigious", "significant" goods of unsurpassed quality).

Domestic manufacturers of the food industry, confectionery in particular, do not use sophisticated communication systems to maintain contact with intermediaries and counterparties. Promotion of the domestic confectionery product is carried out by using a certain proportion of Internet advertising and sales promotion methods, ignoring personal sales and communication methods due to their high cost and significant time expenditures illustrated in Table 1.1. 
Table 1.

Features of enterprises' marketing communications in promoting products on the foreign markets [8]

\begin{tabular}{|c|c|}
\hline Advertising & Personal Sales \\
\hline $\begin{array}{l}\text { Typical means are Internet advertising and } \\
\text { advertising in printed media, mostly of a highly } \\
\text { specialized nature, as a tool for mass audience coverage } \\
\text { and multiple influences and persuasions. } \\
\text { There are significant costs in the case of using } \\
\text { professional foreign intermediaries }\end{array}$ & $\begin{array}{l}\text { The personal character of this marketing } \\
\text { communication makes it the most expensive in terms of } \\
\text { one foreign economic contact. }\end{array}$ \\
\hline Propaganda & Direct Marketing \\
\hline $\begin{array}{l}\text { This type of marketing communication is not } \\
\text { typical in promoting products to the external market. }\end{array}$ & $\begin{array}{l}\text { It is used in the form of address requests both in } \\
\text { direct (offer) and reverse order (request or order) and } \\
\text { prevails in the search for a potential counterparty } \\
\text { (direct) and established foreign trade relations (reverse). } \\
\text { This type is characterized by high reliability of } \\
\text { information, trust in it counteragent and long-lasting } \\
\text { effect, aimed at forming a stable customer loyalty to one } \\
\text { brand. }\end{array}$ \\
\hline Public Relations & Promotion of sales \\
\hline $\begin{array}{l}\text { As propaganda is not typical for the foreign trade } \\
\text { practice of promoting products through its predominant } \\
\text { form of news, which are usually additions to } \\
\text { advertising. }\end{array}$ & $\begin{array}{l}\text { It has a short-term effect; therefore, in the } \\
\text { relations with permanent contractors, it is usually } \\
\text { supplemented by advertising of new export-oriented } \\
\text { products. }\end{array}$ \\
\hline
\end{tabular}

By directing its communication efforts to potential counterparties, the company hopes for the feedback especially from potential importers - purchases of the enterprise's goods; from potential exporters and marketing foreign intermediaries - cooperation on mutually beneficial terms; from state authorities - formation of the most favored regime. Each of these groups of influence's means is characterized by specific communication techniques: exhibitions, fairs, product demonstrations, exhibitions in sales places. At the same time, the communication efforts are also the registration of goods, packaging, and even the gratitude of the enterprise for the purchase.

Analyzing the actual effectiveness of using the marketing potential at the industrial enterprises of the confectionery industry in Ukraine and the main trends of its development, it can be assumed that in the near future the main focus of marketing activities will be market segmentation and product placement in order to develop marketing relations. In Ukraine, it is expected the strengthening of the consumers' economic separation by their purchasing ability, so it is possible to assume that domestic consumers will form a different attitude to food, which will lead to the development of differentiated assortment of goods, designed for different price segments of the market in all sectors of the food industry, herewith the particular importance will be research in the field of category management [9].

Most Ukrainians are positive about taking part in surveys and marketing research, it can be assumed that this circumstance creates the perspective of establishing good relations between producers and consumers, and this may serve as the basis for further development of the food market.

So, after analyzing the theoretical promotion policy, we can clearly say that the promotion of products is an integral part of bringing the products to the final user.

The longest stage in the life cycle of a product is maturity. At this stage, it is recommended that all forces are directed to maintain market positions. In order to stimulate demand, it is necessary to apply mostly reminding advertising and stimulating discounts.

In the end, the sale of a certain variety or brand of goods still starts to fall. At this stage, PJSC "Dominic" should use intensive sales promotion with the help of new advertising, personal sales and propaganda. 
According to the existing and proposed measures, we can say that the choice of stimulating demand means for products of PJSC "Dominic", taking into account the life cycle of the product, will allow the company to quickly distribute information about the release of new goods on the market, to gain the affection of a large audience with a rapid pace and to maintain demand at the high level as long as possible.

In order to increase the efficiency of goods promotion of PJSC "Dominic", it will be advisable to use additional stimulation methods such as, for example, merchandising, drawings and lotteries, tasting and demonstration of goods, gifts for purchase, etc. This will allow accelerating the process of product penetration into the market, and therefore shortening the time to achieve profit, and will provide the opportunity to attract a wider range of consumers, which, accordingly, will improve the competitiveness of the enterprise as a whole.

Determining the effectiveness of stimulation means is an important element of the promoting process of the product and advertising activities of each enterprise, in particular PJSC "Dominic", and is a significant factor in improving overall efficiency and profitability of entrepreneurial activity.

Also, we propose to implement a special system of discounts on products, we have developed a discount card model of 5,10 and 15\% in Figure 1.1. These discount cards can be applied as following:

1) To be issued to customers when products' of the trademark "Dominic" purchase is for the amount of 75, 100 and $150 \mathrm{UAH}$ in one check at the appropriate point of sale of the company.

2) To use as a promotional line for the sale of certain products, a corresponding discount card will be provided to a certain package for the next purchase of trademark "Dominic" products.

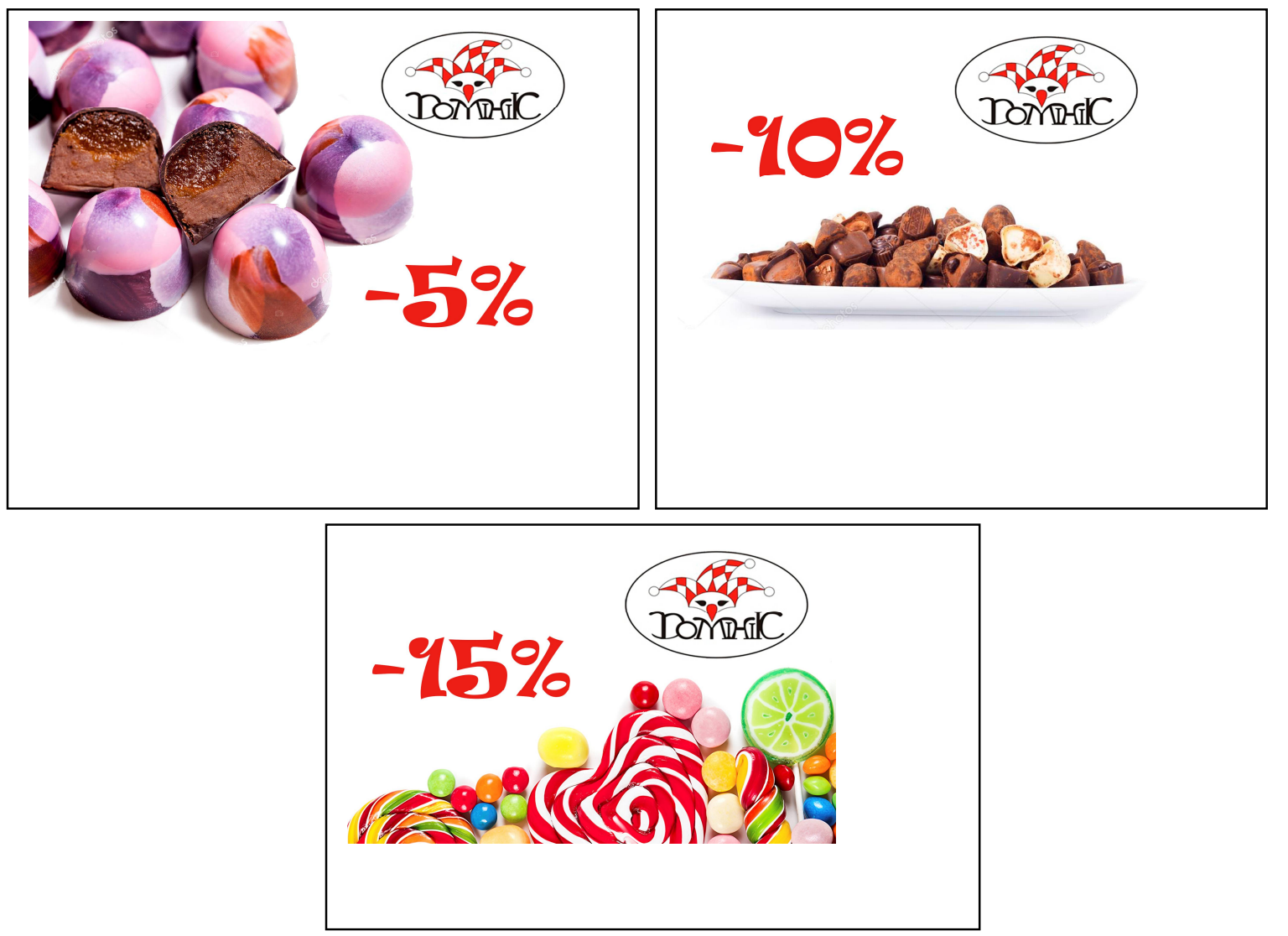

Fig. 1. Discount cards for trademark "Dominic" 
In addition, we propose to provide updated brand packaging (packages). When you visit a shop, a customer buys products and gets a package with the Dominic logo for free. Due to this, the logo can be seen by thousands of people, because they can be used quite often and in places where there is a great crowd of people. We have developed our own example of a paper package, Figure 1.2 .

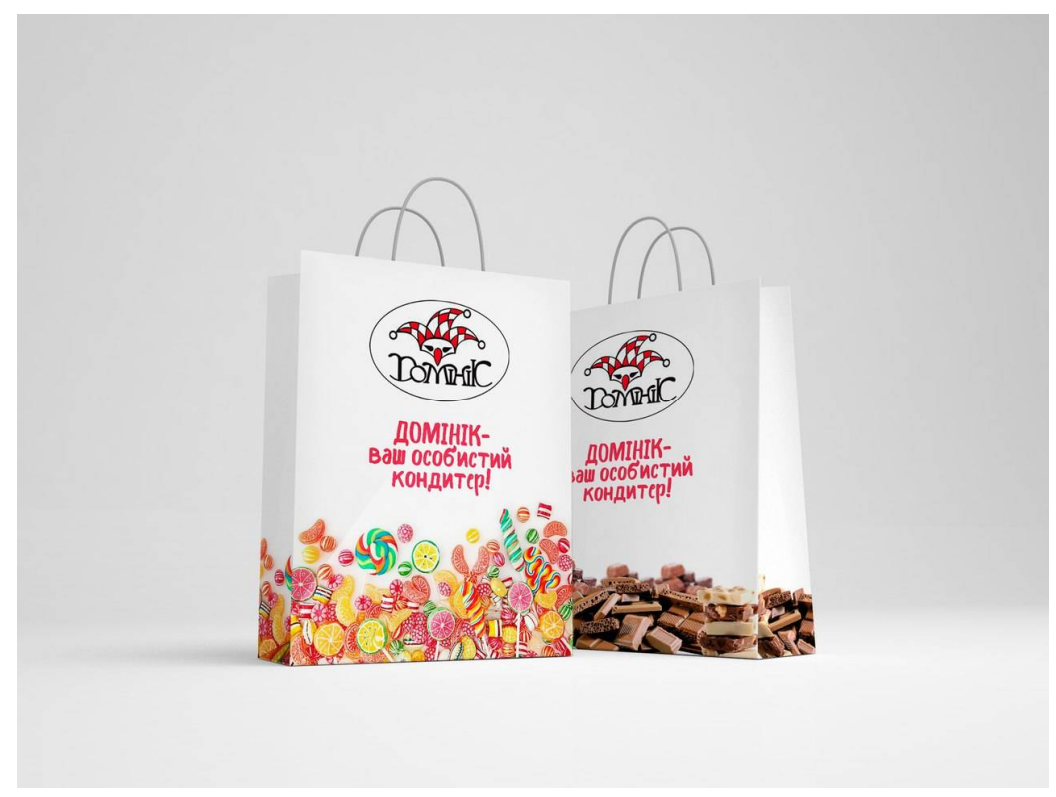

Fig. 1. Paper package for trademark "Dominic"

In addition, these solid paper packages can be a simple alternative to polyethylene bags, since recycled eco-bags or conventional woven bags with the logo of the trademark "Dominic", in which any goods can be delivered, will not only be a mean of daily packaging, but also environmentally effective product. Since, according to ecologists, each of us uses about three hundred different bags per year. Polyethylene decomposes for more than a hundred years.

Thus, from the above mentioned promotion means not only advertising is one of the main components of the stimulation of sales, which expands sales markets, helps to accelerate the turnover of funds, by which increases the efficiency of production in general. We have offered several options for improvement and updating regarding the promotion policy of PJSC Dominic.

\section{REFERENCES:}

1. Bozhkova V.V. Advertising and sales promotion: textbook. / V.V. Bozhkova, Yu. M. Melnyk. - K. : CUL, 2014. - 200 p.

2. Astahova I. E. Marketing: textbook. Kharkiv National University of Economics . / I. E. Astahova. - Kharkiv : Publs. KhNUE, 2011. - 208 p.

3. Hryhorchuk T. V. Marketing. Part two: textbook / T. V. Hryhorchuk. - K. : Ukraine, 2016. $-300 \mathrm{p}$.

4. Bai S.I. Management of Organizations: manual / S.I. Bai. - K. : KNUTE. - 2014. - 174 p.

5. Heiets V.M. Innovative prospects of Ukraine: manual / V.M. Heyets, V.P. Semynozhenko. $-3^{\text {rd }}$ edition. - Kharkiv : Konstanta, 2014. -272 p.

6. Holubkova E. N. The impact of light, color, shape and corporate symbols on the perception of the advertised product / E. N. Holubkova [Electronic resource]. - Access mode: http://mavriz.ru/annotations/2009/4/. 
7. Hryshchenko I. M. Marketing base of commercial mediation textbook. / I. M. Hryshchenko. - K. : Hramota, 2017. -303 p.

8. Life cycle of product. Types of life cycles [Electronic resource].- Access mode: https://sites.google.com/site/marketingdistance/tema-5/5-5-zittevij-cikl-tovaru.

9. Research of confectionery products competitiveness [Electronic resource]. - Access mode: http://otherreferats.allbest.ru/marketing/.

\section{УДК 339.138:338.349.4}

Мокляк Мирослава Володимирівна, кандидат технічних наук, доцент. Передерій Ярослав Олександрович, магістр. Полтавський національний технічний університет імені Юрія Кондратюка. Сафонов Микола Сергійович, підприємець ТОВ «Алмаз ЛТД». Особливості промоційної політики кондитерської промисловості.

Визначено сутність та мету процесу просування продукції на ринок, конкретизовано етапи іiі просування. Розглянуто особливості організації цього процесу з урахуванням специфіки продукції. Запропоновано алгоритм удосконалення технологій, організації процесів виробництва й управління підприємством під час просування на ринок інноваційної продукції. Нові форми стимулювання, організаційні структури,методи розролення управлінських рішень - усе це інноваційна продукція.

3 метою прискорення та підвищення якості процесу просування продукції на ринок суб'єктам господарювання запропоновано ділитися своїми знаннями про потенційних споживачів із партнерами. Сучасною тенденцією організації процесу просування продукції на ринок $є$ пошук підприємствами вертикальних і горизонтальних інтеграційних зв'язків один 3 одним, що зумовлено дефіцитом власних фінансових коштів, подорожчанням позикових ресурсів, ускладненням залучення інвестицій, зниженням тривалості життєвого циклу інноваційної продукції, необхідністю комплексного використання різних методів просування й іншими факторами.

Крім того, приділено увагу дослідженню особливостей політики просування підприємства кондитерської галузі. Розглянуто теоретичні, методичні засади формування i реалізації політики просування на підприємствах кондитерської промисловості.

Досліджено чинники, які треба враховувати при розробленні виходу на нові ринки. Розглянуто основні напрями, за котрими працюють підприємства кондитерської галузі, а також конкурентні переваги, які отримує підприємство шляхом здійснення політики просування. Більш детально проаналізовано політику просування на прикладі діяльності кондитерської фірми «Домінік». На основі виконаного аналізу обгрунтовано припущення, що в кондитерській галузі доцільно вводити новітні сучасні методи просування продукції 3 метою отримання підприємств-лідерів.

Розглянуто подальші перспективи галузі з урахуванням налагодження виробництва функціональних кондитерських виробів.

Ключові слова: ринок, продукція, кондитерські вироби, підприємство, технології. 
UDC 339.138:338.349.4

Myroslava Mokliak, Ph.D., Associate Professor. Yaroslav Perederii. Poltava National Technical Yuri Kondratyuk University. Mykola Safonov, businessman of LTD "Diamond LTD". Features of the promotion policy of the confectionery industry. The article defines the essence and purpose of the product promotion process on the market, the specified stages of its promotion. The organization features of this process taking into account product specifics are considered. The algorithm of technologies improvement, organization of production processes and management of the enterprise during the innovative products promotion on the market is offered. New forms of stimulation, organizational structures and methods for developing managerial decisions are all innovative products. In order to accelerate and improve the quality of the product promotion process on the market, business entities are encouraged to share their knowledge of potential customers with partners.

The modern tendency of organizing the product promotion process on the market is the search for enterprises of vertical and horizontal international links with each other due to the shortage of own funds, rising cost of borrowed resources, the complication of attracting investments, reducing the life cycle of innovative products, the need for the integrated use of various methods of promotion and other factors. In addition, the attention was paid to the study of the promotion policy specifics in the confectionery industry. The theoretical, methodological principles of formation and implementation of the promotion policy at the confectionery industry enterprises are considered. The factors that need to be taken into account while developing new markets are described in the article. The main directions of the confectionery industry enterprises, as well as the competitive advantages that the enterprise receives through promotion policy, are considered.

The promotion policy is more detailed analyzed on the example of the confectionery firm "Dominic". Based on the made analysis, the assumption was made that in the confectionery industry it is expedient to introduce the latest modern methods of product promotion in order to obtain the leading enterprises. Further perspectives of the industry, taking into account the establishment of functional confectionery products production, are considered. enterprise,

Keywords: market, products, confectionery, technology.
УДК 339.138:338.349.4

Мокляк Мирослава Владимировна, кандидат технических наук, доцент. Передерий Ярослав Александрович, магистр. Полтавский национальный технический университет имени Юрия Кондратюка. Сафонов Николай Сергеевич, предприниматель ООО «Алмаз ЛТД». Особенности промо политики кондитерской промышленности. Определены сущность и цель процесса продвижения продукции на рынок, конкретизированы этапы ее продвижения. Рассмотрены особенности организации этого процесса с учетом специфики продукции. Предложен алгоритм совершенствования технологий, организации процессов производства и управления предприятием при продвижении на рынок инновационной продукции. Новые формы стимулирования, организационные структуры, методы разработки управленческих решений все это инновационная продукция. С целью ускорения и повышения качества процесса продвижения продукции на рынок субъектам хозяйствования предложено делиться своими знаниями о потенциальных потребителях с партнерами. Современной тенденцией организации процесса продвижения продукции на рынок является поиск предприятиями вертикальных и горизонтальных интеграционных связей друг с другом, что обусловлено дефицитом собственных финансовых средств, удорожанием заемных ресурсов, осложнением привлечения инвестиций, снижением продолжительности жизненного цикла инновационной продукции, необходимостью комплексного использования различных методов продвижения и другими факторами. Кроме того, уделено внимание исследованию особенностей политики продвижения предприятия кондитерской отрасли. Рассмотрены теоретические, методические основы формирования и реализации политики продвижения на предприятиях кондитерской промышленности. Исследованы факторы, которые необходимо учитывать при разработке выхода на новые рынки. Рассмотрены основные направления, по которым работают предприятия кондитерской отрасли, а также конкурентные преимущества, которые получает предприятие путем проведения политики продвижения. Более подробно проанализирована политика продвижения на примере кондитерской фирмы «Доминик». На основе проведенного анализа обосновано предположение, что в кондитерской отрасли целесообразно вводить новейшие современные методы продвижения продукции с целью получения предприятий-лидеров. Рассмотрены дальнейшие перспективы отрасли с учетом налаживания производства функциональных кондитерских изделий.

Ключевые слова: рынок, продукция, кондитерские изделия, предприятие, технологии. 